IRA-International Journal of Management \& Social Sciences

ISSN 2455-2267; Vol.06, Issue 02 (2017)

Pg. no. 253-259

Institute of Research Advances

http://research-advances.org/index.php/RAJMSS

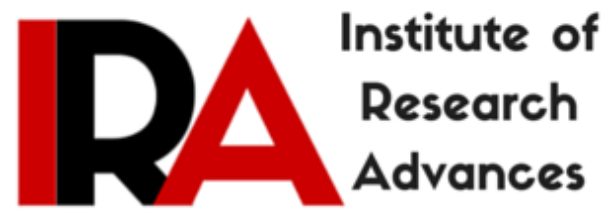

\title{
Digitalization in India: A Needed Gadget for Business Environment
}

\section{Dr. P. Subramanyachary}

Professor, Department of MBA,

Siddharth Institute of Engineering and Technology,

Puttur -517583, Chittoor District, Andhra Pradesh, India.

Type of Review: Peer Reviewed.

DOI: http://dx.doi.org/10.21013/jmss.v6.n2.p8

How to cite this paper:

Subramanyachary, P. (2017). Digitalization in India: A Needed Gadget for Business Environment. IRA-International Journal of Management \& Social Sciences (ISSN 2455-2267), 6(2), 253-259. doi:http://dx.doi.org/10.21013/jmss.v6.n2.p8

(C) Institute of Research Advances

(c)) EY-NO

This work is licensed under a Creative Commons Attribution-Non Commercial 4.0 International License subject to proper citation to the publication source of the work.

Disclaimer: The scholarly papers as reviewed and published by the Institute of Research Advances (IRA) are the views and opinions of their respective authors and are not the views or opinions of the IRA. The IRA disclaims of any harm or loss caused due to the published content to any party. 


\begin{abstract}
This paper brings to light the importance, challenges and advantages of digitalization in India. Digitalization refers the adoption or increase in use of digital or computer technology by an organization, industry, country, etc. The relative close word Digitization refers an object, image, sound, document or a signal by generating a series of numbers that describe a discrete set of its points. In the world the digital economy is the new productivity platform which is regarded as the third industrial revolution. India is an initiative of the Central Government of India "designed to transform India into a global digitized hub" by reviving a rundown digital sector of India with the help of improving digital connectivity and skill enhancement and various other incentives to make the country digitally empowered in the field of technology. The Union Government in 2016 announced 11 technology initiatives that include the use data analytics to nab tax evaders, creating a substantial opportunity for IT companies to build out the systems that will be required. But the initiatives are suffering from lacks many components like lack of legal framework, absence of privacy and data protection laws, hindrances to civil liberties, lack of parliamentary oversight for e-surveillance in India, lack of intelligence related reforms in India, insecurity of Indian cyberspace, etc. It is mandatory that economy has to push merits of Digitalization and check the problems arise from digitalization. In the era of Globalization transactions are increasing. Hence, digitalization is to be given priority for both quick and transparent business transactions.
\end{abstract}

Key Words: Digitalization, Internet of Things, E- Commerce, Digital India

\title{
INTRODUCTION:
}

Digitalization refers the adoption or increase in use of digital or computer technology by an organization, industry, country, etc. The relative close word Digitization refers an object, image, sound, document or a signal by generating a series of numbers that describe a discrete set of its points. In the world the digital economy is the new productivity platform which is regarded as the third industrial revolution. This is also known as 'The Internet Economy' or Internet of Everything (IoE) and expected to generate new market growth opportunities, jobs and become the biggest business opportunity of mankind in the next 30 to 40 years. The momentum that 'Digital India' has given to our technological progress is noteworthy indeed. Digital India Program is a national campaign to transform India into a globally connected hub. It has different proposals as well as incentives to the companies, basically the manufacturing companies where both domestic and foreign to invest in India and make the country to be a digital destination. The emphasis of Digital India campaign is on creating jobs and skill enhancement in the Broadband Highways, e-Governance, and Electronic delivery of services, Universal access to Mobile Connectivity, Electronics Manufacturing, and Information for All etc. The campaign aims at to resolve the problems of connectivity and help us to connect with each other and also to share information on issues and concerns faced by us. In some cases they also enable resolution of those issues in near real time. Digital India is an initiative of the Central Government of India "designed to transform India into a global digitized hub" by reviving a rundown digital sector of India with the help of improving digital connectivity and skill enhancement and various other incentives to make the country digitally empowered in the field of technology.

\section{DEFINITIONS:}

Integration of digital technologies into everyday life by the digitization of everything that can be Digitalized: -Business Dictionary

Digitalization is the way in which many domains of social life are restructured around digital communication and media infrastructures. In the pages that follow, we discuss these distinct, yet interrelated, concepts.-Oxford Dictionary 


\section{PILLERS OF DIGITALIZATION:}

There are several pillars of opportunities that are going to be built to escalate public behavior and expectation in digital way:

1. Broadband Highways

2. Digital Locker

3.Mobile Connectivity

4.E-Kranti

5. Jobs

6.Manufacturing

7.MyGov

8.Information for All

9. Scope with Foreign Universities

\section{ADVANTAGES}

The advantages of Digitalization include Customer experience, Technology push, and Economic benefits along with the following advantages.

1. Digital Empowerment of Native Indian People.

2. Delivery of all Government Services electronically (E-Governance).

3. A Digital Identification which will verify the end user. A Mobile for worldwide access to all services will help in getting things done easily.

4. A Bank account for Immediate Benefit Transfers of subsidies and payments.

5. The program also aims to eliminate all electronics imports from foreign countries by 2020 and make India a electronics manufacturing super power

6. It will help in decreasing crime if applied on whole.

7. It will help in decreasing documentation which helps to protect trees and environment.

8. Some of the services which will be provided through this desire effort are Digital Locker, e-education, e-health, e-sign and nationwide scholarship portal.

9. It will ostensibly create a lot of jobs.

10. It will be a boost to industry; both large and small enterprises.

\section{DISADVANTAGES}

The following are disadvantages of Digitalization.

1. Government employment may reduce which in turns to civil servants' unrest.

2. People may misuse free Wi-Fi just for time pass which is current scenario in metros.

3. Illiteracy people may lose with digitalisation as they are not aware of it.

4. Cybercrimes may increase. Now India is at $3^{\text {rd }}$ place having cyber threat.

5. It impacts unemployment problem.

\section{DIGITALISATION IN INDIA}

Digital India is a campaign launched by the Government of India to ensure that Government services are made available to citizens electronically by improving online infrastructure and by increasing Internet connectivity or by making the country digitally empowered in the field of technology. Digital India was launched on 1 July 2015 by Prime Minister Narendra Modi. The initiative of this concept includes plans to connect rural areas with high-speed internet networks. Digital India consists of three core components. They are 1.The creation of digital infrastructure 2.Delivery of services digitally 3. 
Digital literacy. The vision of Digital India program is one that has inclusive growth in the areas of electronic services, products, manufacturing and job opportunities etc. It also focused on three key areas namely - Digital Infrastructure as a Utility to Every Citizen, Governance \& Services on Demand and Digital Empowerment of Citizens. The Government of India entity Bharat Broadband Network Limited which executes the National Optical Fabre Network project will be the custodian of Digital India (DI) project. The BBNL had ordered United Telecoms Limited to connect 250,000 villages through Gigabit Passive Optimal Network (GPON) to ensure Fabre to the Home (FTTH) based broadband. This provides the first basic setup to achieve towards Digital India and is expected to be completed by the year 2017.The government is planning to create 28,000 seats of BPOs in different states and set up at least one Common Service Centre in each of the Gram Panchayats in the every state.

The Union Government in 2016 announced 11 technology initiatives that include the use data analytics to nab tax evaders, creating a substantial opportunity for IT companies to build out the systems that will be required. Digital Literacy mission will cover six crore rural households. There is a plan to connect 550 farmer markets in the country through the use of technology. In India out of $10 \%$ English speaking Indians, only $2 \%$ are reside in rural areas. Rest everyone depends on their vernacular language for all living their lives in their respective locality. However, email addresses can only be created in English language. To connect rural India with the Digital India, the Government already impelled email services provider giants including Gmail, office and Rediff to provide email address in regional Languages. However, the email provider companies have shown positive sign and are working in the same process in this regard. It is proud to say that an Indian based company, Data Xgen Technologies Pvt Ltd, has launched world's first free linguistic email address under the name 'DATAMAIL' which allows to create email ids in 8 Indian languages, English; and 3 foreign languages - Arabic, Russian and Chinese. Over the period of time the email service in 22 languages will be offered by Data XGen Technologies.

\section{OPPORTUNITIES:}

A Digital India Year would make sure that each and every aspect of the program must be pushed to show results on the ground and not go into hibernation after one week of enthusiasm. Considering that most of the nine pillars of the Digital India program face serious challenges in implementation, it is imperative that focused, persistent attention be given to each of its pillars so that the big program does not end up in embarrassment and failure. Digital Empowerment Foundation has a footprint at more than 150 locations in India at the village level, and that too with the purpose of digitally enabling the poor. There are some of the major challenges of the Digital India program.

The first and major challenge is that the entire program is designed as a top-down model. There is no idea of how it would be implemented on the ground to be successful as much as desirable. For example, let's consider six of the nine pillars of the program directly related to consumers and people at large: broadband highways, universal access to mobile connectivity, public Internet access program ekranti or electronic delivery of services, information for all, and IT for jobs. Besides these Broadband highways, now called BharatNet, is supposed to connect up to gram panchayat, but laying fiber optic cables is the least of the challenges here. The biggest challenge towards this is ensuring that each panchayat point of broadband is fired up, functional, used and distributed. Our research work found that more than $67 \%$ of the National Optical Fibre Network (NOFN) points are non-functional, even at the pilot stage. Besides, if the broadband highways programme is not implemented well and soon, we may not be able to implement other pillars of the programme, such as the public Internet access program, e-kranti, information for all, and even IT for jobs. All these are dependent on access infrastructure.

Out of the many initiatives launched during the Digital India week, one that could make a serious impact is BSNL's (Bharat Sanchar Nigam Ltd) mass deployment of Wi-Fi hotspots across the 
country. If the government pushes BSNL to ensure at least one hotspot per panchayat or per village, it can do wonders, and the government can also show off this as a positive outcome. However, if the selection of the locations for the hotspots necessarily were those populated by mostly tribals, backward castes, and minorities and geographically difficult areas, then the impact would be something that would be a national story. A well-connected nation is a prerequisite to a well served nation. Once the remote villagers are digitally connected through broadband and high speed Internet, then delivery of electronic government services to every citizen, targeted social benefits and financial inclusion can be achieved in reality. One of the basic and key areas on which the vision of Digital India is centered digital infrastructure as a utility to every citizen of India.

Another key component under this vision is high speed Internet as a core utility to facilitate online delivery of various services. Government planned to set up enabling infrastructure for digital identity, financial inclusion and ensure easy availability of common services centers. The vision also proposed to provide citizens with 'digital lockers' which would be sharable private spaces on a public cloud and where documents issued by government departments and agencies could be stored for easy online access for further transactions. It is also planned to ensure that the cyberspace is made safe and secure forever. A large number of initiatives have been undertaken by various State Governments and Central Ministries to usher in an era of e-governance. Sustained efforts have been made at multiple levels to improve the delivery of public services and simplify the process of accessing them. E-governance in India has steadily evolved from computerization of Government Departments to initiatives that encapsulate the finer points of Governance, such as citizen centricity, social responsibility, service orientation transparency, accountability etc. that makes the Indian economy efficient. As part of this digitalization of the economy the National e-Governance Plan (NeGP) was approved in 2006 to take a holistic view of e-governance initiatives across the country, integrating them into a collective vision. Towards this idea, in India a massive countrywide infrastructure reaching down to the remotest of villages is being developed and large-scale digitization of records is taking place to enable easy and reliable access over the Internet. The ultimate objective was to make all government services accessible to the common man in his locality, through common service delivery outlets, and ensure efficiency, transparency and reliability of such services at affordable costs to realize the basic needs of the common man.

If we take example Communications and IT development, Today, Sanchar Bhawan is free from middlemen, there is no scam or scandal, and decisions are taken in a free and fair manner. We had the highest spectrum auction ever of 1.10 lakh crore (last year). All the policy initiatives pending for the past 7 to 10years defence band identification, spectrum trading sharing, harmonization, liberalization, cloud policies, open source in IT and creating an ecosystem of sound investment - are in place. As a result, IT and IT enabled exports today are worth $\$ 108$ billion, the highest ever in the history of India. India has received \$4,091 million (over Rs.26,000 crore) foreign direct investment in telecom. Mobile telephony has shown growth. The postal sector had tremendous growth of Rs.122.66 million between April 2014 and February 2016.India crossed one billion mobile phones under our government, one billion plus Aadhaar cards and 400 million plus Internet users. On a lighter note, Tele Communications Ministry said that net addition in total telephony (mobile plus landline) from April 2014 to February 2016 is equivalent to the population of France and Italy put together. The growth rate of total telephony, which was 3.90 per cent in 2013-14, posted 6.76 per cent in 2014-15, and 5.65 per cent till February this year, and it is sure that the rate must have crossed 6.50 per cent in March 2016. This is the position - a clear growth - and what is important is the rural growth is more than the urban. Rural tele-density has increased 6.62 per cent between February 2014 and February 2016. Therefore, the telecom sector is rising and with 'Digital India', it is going to rise further. Another important hopeful victory is the recovery of the postal department. Postal services have become the biggest deliverer of e-commerce items - there are more than 57 centers in the country, fully automated and computerized for services. The e-commerce 
parcel revenue, which was down 2 per cent in 2013-14, rose 45 per cent in 2014-15 and 80 per cent in 2015-16, and by February, it has reached 100 per cent.

\section{CHALLENGES}

The challenges of digitalization in India are more. The general drawbacks include lack of legal framework, absence of privacy and data protection laws, civil liberties abuse possibilities, lack of parliamentary oversight for e-surveillance in India, lack of intelligence related reforms in India, insecure Indian cyberspace, etc. Some other challenges are mentioned below.

Implementation of Programs: The entire program is designed as a top level model on the technological front. There is hardly any guidance regarding to implement the same on the ground level to make it successful. To be precise, most of the nine pillars of the program are directly related to high-end consumers in urban areas and not for $70 \%$ of the rural population in India. Deploy Wi-Fi Centers \& Hotspot: BSNL's (Bharat Sanchar Nigam Ltd) mass deployment of Wi-Fi hotspots across the country. If the government pushes BSNL to ensure at least one hotspot per village, it can do wonders and experience the positive outcome. However, if the selection of the hotspot locations were those populated by mostly tribal backward castes, minorities and geographically difficult areas, then the impact can bring a new era in the life styles and other culture of the people in our country significantly and also impact other countries.

Improvement of IT Literacy: Improving IT literacy is very important because the entire mass who is using internet should know how to secure his/her online data. Providing proper usability guidance of Anti-Virus software and its role in securing the records should happen simultaneously to avoid illegal things in all the economic and other money transactions. Data Vulnerability: Each and every citizen of India would have all the personal details online including bank details, Income tax details, PAN details which might be vulnerable if not secured properly. In case this is breached, then any individual would lose the privacy of the data and would be compromised. This leads to lose of personal money in the form digital transactions. Excessive Server Hits: If majority of the population start using online, then definitely the Government portal sever will start getting more number of hits day by day. This is limitless and the IT team needs to be prepared to tackle the situation where the possibility of crash would minimize. Man-In-The-Middle Attack: It is a type of cyber-attack where a malicious actor intrudes him/ herself into a conversation between two parties, imitates both parties and gains access to information that the two parties were trying to send to each other. A man-in-the-middle attack allows such intercepts of the data meant for someone else, without knowledge of either of the party until it is too late.

\section{IMPACT OF DIGITALISATION BY 2020 IN INDIA:}

The government of India is taking steps to promote digitalization in business transactions. Hence digital transactions are increasing due to usage of Smart Phones, Internet Availability and expansion of banking services with debit and credit cards. In India 86\% transactions are going on. Demonetization brought down cash transactions to $78 \%$. The cash transactions are below $25 \%$ in developed countries due to smart cards are being used for every transaction like transport, restaurant, super markets, taxi, parking etc. For example Apple Pay in Japan, Octopus Card in Honkong, Myki card in Australia. India has only $22 \%$ of cashless transactions. Contrary to this in other countries this is more. For example Belgium 95\%, France 93\% Canada 91\%, Britain 90\%, America 72\%, Korea 70\%.

According to the Boston Consultancy Group (BCG) report by 2020 the worth of digital payments will be reached 500 billion dollars (Rs. 34,00,000 crores) in India. It also estimated that the cashless transactions will be $40 \%$ by 2020 ; further the percentage goes to $59 \%$ by 2025 . It also estimated that the digital payment industry reaches the worth of 5 billion dollars (Rs. 3, 40,000 crores) by 2020 . 


\section{Some other impacts are given below:}

1. Broadband in 2.5 lakh villages, universal phone connectivity

2. Net Zero Imports by 2020

3. 400,000 Public Internet Access Points

4. Wi-fi in 2.5 lakh schools, all universities; Public Wi-Fi hotspots for citizens

5. Digital Inclusion: $1.7 \mathrm{Cr}$ trained for IT, Telecom and Electronics Jobs

6. Job creation: Direct $1.7 \mathrm{Cr}$. and Indirect at least 8.5 Cr.

7. e-Governance \& eServices: Across government

8. India to be leader in IT use in services - health, education, banking Digitally empowered citizens - public cloud, internet access

\section{CONCLUSION:}

Since Technology advances as time passes every economy and individual has to adopt upcoming technology for digitalization. It is mandatory that economy has to push merits of Digitalization and check the problems arise from digitalization. In the era of Globalization transactions are increasing day by day. So that digitalization to be given priority for both quick and transparent transactions.

\section{REFERENCES}

1. EY, Digitization of Everything, 2011

2. Kelly, Kevin (May 14, 2006). "Scan This Book!". New York Times. Retrieved 2016-10-26

3. Mazars, Digitalization: A Vehicle of the New Age of transformation, 2011

4. PWC, Managing for Performance: Transaction Banking, 2012

5. www.digitalindia.gov.in

6. www.dnaindia.com

7. www.dqindia.com.

8. www.ncaer.org. 